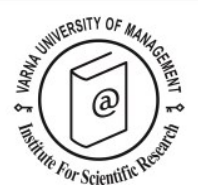

\title{
Analyzing Destination Attributes Under Fuzzy Environment: A Case Study in Eskişehir
}

\author{
Ramazan Ufuk Bayer ${ }^{1}$ and Çağlar Karamaşa ${ }^{2 *}$
}

Received: 25/08/2016 Accepted: 31/07/2017

\footnotetext{
1 Department of Hospitality Management, Faculty of Business, Anadolu University 26470, Eskişehir, Turkey

2 Department of Business Administration, Faculty of Business, Anadolu University 26470, Eskişehir, Turkey; email: ckaramasa@hotmail.com, tel: +905395222803

* Corresponding author
}

\begin{abstract}
Given the understanding that destination attributes will often provide access to deep rooted knowledge repositories as well as offer historic facts, for a given tourist destination, it is vital to mention that there still is insufficient research being undertaken, conceptual or empirical, on the subject. Therefore, it is believed more research effort is required to further develop and increase knowledge on this subject matter. This study being carried out is in a bid to contribute towards the continued development of this body of knowledge and to also, increase domain expertise in this field. Within this study, there were two main objectives. First, was the ranking of Eskişehir's - one of Turkey's well-known cultural destinations - destination attributes in terms of its relative importance, by making use of tourism experts' opinions. A fuzzy ranking methodology was adopted to help achieve this output for the study. Recognizing there are several fuzzy ranking approaches covered in our literature review, the choice made was to adopt the four most commonly used methodologies for the study. Hence, the second objective of this study was to test for statistically significant differences, between output results from all four fuzzy ranking methodologies adopted. This study is equally important because it contributes to the body of knowledge exploring the adoption and use of fuzzy ranking, in the evaluation of destination attributes. Consequently, results from this research will offer a guide to other researchers planning to apply fuzzy ranking to similar studies.
\end{abstract}

(C) 2018 Varna University of Management. All rights reserved

Keywords: Destination attributes; Eskişehir; Fuzzy ranking; Statistical significance; Tourism.

Citation: Bayer, R., Ç. Karamaşa (2018) Analyzing Destination Attributes Under Fuzzy Environment: A Case Study in Eskişehir. European Journal of Tourism Research 18, pp. 75-94

\section{Introduction}

It is generally understood that a business will adopt various methodologies and approaches, available to it in its bid to evaluate and gain a better perspective of its current situation.
Following the execution of such evaluations, businesses are offered the opportunity of becoming aware of their strengths, which must be maintained; as well as their weaknesses, which must be improved upon. By analyzing a 
businesses' existing state, this provides it the benefit of better understanding itself today and then, helps it develop strategies that can offer it a brighter future. Given the emphasis management teams for businesses attach to the evaluation of their current positions, so also do management teams for destination venues and locations. Tisdell (1991) states tourism is dependent on the availability and access to natural, cultural, man-made and other relevant resources. Consequently, the management teams for such destinations would seek to better manage such attributes with the intention of making tourism destinations more successful and attractive. Hence, in line with such objectives, it becomes vital to analyze the existing status of destination attributes.

The handling of destination attributes, conceptually, requires an explanation of motivating theories. Although there are different motivations and approaches from within the context of tourism, a well-accepted motivation theory for tourists is the 'push and pull' motivation theory (Cook, Yale \& Marqua, 2010, p.34). The push and pull theory provides a simple and intuitive approach that attempts to explain the motivations underlying tourist behavior (Dann, 1977). Pizam and Mansfeld (1999, p.212) state the motivation to go on a holiday 'pushes' the potential tourist into a decision whilst attributes of the destination, 'pulls' the holidaymaker to select a particular destination. In literature examined by this study, different terms like tourism supply, destination attractions, resources and attributes, are interchangeably used instead of pull factors. However, for this study the term destination attribute is the preferred phrase used because it corresponds more with variables for this study. There, however, will be no discussion on the role of destination attributes within tourism.

It remains a fact that destination attributes have acted as catalyst and offered an inspiration for a tourists' decision, even with the postmodern tourists of where to travel to, throughout history. Although destination attribute themes are not considered contemporary issues in tourism, the concept however, is viewed as not being explicitly clear due to the inadequacy of theoretical and applied researches (Chacho \& Fenich, 2000; Zhou, 2005; Mihalic, 2013).
Researchers will have to undertake many more qualitative and quantitative studies as well as research, in order to bridge the gap existing within available literature on this theme. This study will contribute to the available literature on this theme as well as offer empirical output. In light of this, the aim for this study will be two pronged. The first aim is the ranking of Eskişehir's destination attributes according to its relative importance, by making use of the evaluation of tourism experts. Eskişehir, located in Central Anatolia Turkey, has become a highly sought after location and lively college town with amenities and cultural activities on offer (Yolal, Çetinel \& Uysal, 2009). Eskişehir is not only identified, as an important industrial town and transport hub but is also identified as possessing a high tourism potential, especially for domestic tourism given Eskişehir's cultural affiliations, historical resources, socio-cultural values, entertainment facilities and its ease of access.

Every destination offers every anticipated visitor, a wide range of attributes to explore and experience. Hence, assuming such attributes can impose an equal level of impact, of its perceived attractiveness, for a given destination, should not be presented as a reasonable assertion. Consequently, each destination attribute should be evaluated and prioritized individually, given attributes may be considered as being of greater value or of more importance than others (Swarbrooke \& Horner, 1999; Zhou, 2005; Mikulic, Kresic, Milicevic, Seric \& Curkovic; 2016). By taking into account offered perspectives of various tourism stakeholders', it presents an opportunity to make the evaluation of destination attributes, more valuable. Unfortunately, many studies attempting to focus on this issue will commonly get executed by researchers who collate data from tourists. However, though this cadre of data is considered worthwhile, studies on destination attributes will also require the adoption and use of output and reviews offered from evaluating the perspectives of tourism stakeholders. Given this now presented view, namely expressing the importance of opinions held by tourism experts, data collected by this study will reflect the views of tourism experts and these have been collected within the research. The tourism experts' opinion and view is considered a vital data component and is as an important 
contribution because these experts are among tourism stakeholders that possess the clout and authority to influence decisions, on destination attributes and their affiliated opportunities and issues. In other words, this study attempts to capture and mirror the influence as well as reflect, the likely opinion held by tourism experts whilst also revealing and presenting, results of their perceived views about the destination attributes for Eskişehir.

During the ranking of destination attributes, four of the most commonly used fuzzy ranking approaches have been adopted and are used for this research. An objective for this study is to test if there is a statistical difference between the results being output from the four fuzzy ranking approaches applied, or not. It is intended that these results will offer researchers a guide when planning on using fuzzy ranking and find themselves, confused when deciding on which ranking approach best fits into their study. In addition, this research should be regarded as substantial to the thinking around this theme, given it is believed this will likely define a new approach for the examination of destination attributes by researchers. This study is comprised of five parts and consists' a background to this study being the first section, to introduce a theoretical background and a literature review compiled within its second section. For the third section, this studys' methodology is explained. Whilst the results and output for the study is presented in the fourth section and its conclusion, is the final section.

\section{Conceptual Framework \\ Destination Attributes}

It remains an indisputable fact that destination attributes are of fundamental importance to the tourism industry. Even when offering the definition for a destination, the conceptual description on offer, to describe this destination attribute, becomes more emphasized. Hence, this points to an assigned worth for such a notion. For instance, Leiper (1995) defines a destination as the place or location a tourist decides or chooses to visit in a bid to experience that place's feature, characteristics and attractions. Also Kim (1998) regards a destination as a complex product that comprises of both natural and cultural attributes, as well as its climate, services, infrastructure and superstructure. In addition to the emphasis ascribed to each attribute, for a destination's given definition, the fact that each destination attribute has the capacity to impose some influence on a tourists' destination choice and their decision made, offers an indication of the level of importance that should be assigned to this concept. It is well understood, the tourists' decision-making process may prove to be a complex and lengthy process given it is influenced by numerous variables such as: past experiences; situational influences; personal and economic circumstances; and, social as well as cultural influences (McCabe, 2000; Hudson, 2008). Although an attempt to understand the influence behind a tourists' destination choice or decision, based merely on destination attributes, may seem an output from a narrow-minded set of consideration, however, attributes are the basic foundation for a destination. Ritchie and Crouch (2003) stated if the process of selecting a tourists' destination choice is simplified as best as possible, the core impulse that prompts the tourists' natural desire to visit a given destination, is the only factor left remaining.

Motivation theories are often exploited in a bid to explain the concepts behind destination attributes. Fortunately, most researchers have arrived at a relative consensus, explaining this concept using a "push and pull" theory (Dann, 1977; Crompton, 1979; Pizam \& Mansfeld, 1999; Ritchie \& Crouch, 2003; Pikkemaat, 2004). Even though researchers can be identified as possessing a collective opinion about this theory, whilst attempting to explain destination attributes, they have however described it in different ways. For example, Dann (1977) describes it as 'endogenous and exogenous factors', whilst Uysal and Jurowski (1994) summarize it as using 'internal and external components'. The push factors (endogenous/ internal) are identified as the predictors of the tourists' choice prompting a "decision to travel". Whilst pull factors (exogenous/ external), are identified as predictors of a tourists' decision of "where to travel" (Dann, 1977). Hence, this framework is built upon a two-staged process; effectively, tourists are first pushed by their needs and wants and then, pulled by the destination attributes available. From within the first step, push factors include elements like escape, rest 
and relaxation, opportunities for adventure, prestige, health and social interaction. Whilst for the second step, pull factors rightly named "supply" by Goeldner and Ritchie (2009), is expected to attract the tourist to a specific destination, using its geography, climate, flora and fauna, landscape, superstructure, culture, price, safety etc.

Researchers, as a result, have gone on to develop a diversified approach for categorization, in relation to destination attributes. For instance, as a result of the categorization described, destination attributes can be classified into two groups: given/natural (flora and fauna, climate, mountains, beaches etc.); and, man-made/ artificial (accommodation, recreational areas, transport facilities etc.) (Van Raaij, 1986; Coltman, 1989). Furthermore, destination attributes can also be grouped as: 'functional or tangible' factors; and, 'psychological or abstract' factors (Etchner \& Ritchie, 1993). In addition to this, it will equally be possible to encounter new classifications provided by future research efforts. It will, however, be incorrect and presumptuous to attempt interpreting these efforts at diversification, as a misrepresentation or misunderstanding of the need and issue to hand, because use of differing terms for the same concept offers an opportunity to add a wealth of information to this body of knowledge.

\section{Literature Review}

Within the wider tourism literature, the concept of destination attribute has a deep-rooted history. However, this literature on destination attributes is not sufficiently expanded upon. In describing destination attributes, it incorporates both abstract and concrete elements related to the destination. However, some researchers have taken intangible components into consideration when attempting to scope narratives or descriptions, for destination attributes. The research by Hsu, Tsai and Wu (2009) is one of such studies. They have analyzed the pull factors related to Taiwan and have found the most important pull factors to include: personal safety; destination image; environmental safety as well as quality; and, destination image respectively. In this research, however, just the tangible attributes will be evaluated and so, a broader context for the literature review will be drawn from this direction.

It is recognized that there are ongoing researches that attempt to address the continued development of information on destination attributes, for differing destinations, which provide varied characteristics on destination attributes grouped by its very nature. For instance, Chacho and Fenich (2000) evaluated the importance of destination attributes found to originate from a Convention, Exposition and Meeting Industry (CEMI). It was based on the shared opinions of the meeting planners' and this research showed the top three ranked attributes, were found to be: availability of air service; promotional appeal of city; and, hotel room. In another research, however, the destination attributes for Macau, one of the world's recognized gaming destinations, has been prioritized based on the shared perspective of event tourists, by Wong (2011). These results have uncovered that Macau attracts tourists, primarily with its food offerings as well as its geographic proximity. On the other hand, however, its nightlife entertainment and casino gambling does not have significant effect on Macau's attractivite view.

Apart from researches that concentrate on convention and event tourism, there are researchers whose studies intend to analyze encountered attributes, from the context of destination attributes that have or are likely to become prominent, given their rich natural environment. Correia, Valle and Moço (2007) initiated a study that investigated available attributes, based on how many Portuguese tourists visited exotic destination locations and found the most important attribute to be natural factors, which is considered unsurprising. Also, the study by Çakıcı and Harman (2007) has measured the importance levels assigned to destination attributes, as perceived by Turkish birdwatchers. The findings of this research shows the most important destination attributes identified are as follows: experiencing a natural environment; available clean air; the existence of national parks; an opportunity to observe flora and fauna; and, observe its scenic beauty along the way. Demir (2010) examined Dalyan's attributes, a coastal destination in Turkey, and 
obtained results about its' important attributes, like recreational facilities, socio-cultural values, historical and natural factors respectively.

Evren and Kozak (2012) undertook research for the purpose of determining the impact of pull factors on day visitors to Eskisehir, a cultural and an urban destination in Turkey. The attributes for Eskisehir are then listed according to their assigned level of importance, as follow: recreational parks and excursion areas; local government and Yılmaz Büyükerşen (the mayor of the city); entertainment, education and shopping; and, natural, historical and cultural values. Mihalic (2013) studied destination attributes, taking an in-depth look at importance and performance, from within the borders of Slovenia. They found when ranking attributes based on their importance, they can be listed as: natural; socio-cultural; infrastructure; and, superstructure. Researches that have been examined so far, within the literature for this study, have yielded results as presented above. Hence, it becomes easier to observe that most of the researches examined have revealed in their results and furthermore, will reflect the shared perspective of tourists. There, however, is a deficiency in the literature with regards it presenting the views shared from other tourism stakeholders and this is identified, as one of the main motivations for this research.

The modes for analyzing commonly adopted destination attributes, when undertaking a review of this research's literature, includes: Confirmatory and Exploratory Factor Analysis (CFA-EFA); Importance-Performance Analysis (IPA); Impact-Asymmetry Analysis (IAA); and, Multiple Regression Analysis. Also, it is necessary to note that the AHP (Analytic Hierarchy Process) method was equally applied in some of these studies undertaken. However, the most appropriate assessment method consistent with the defined purpose, for this research, is the use of AHP and the Fuzzy Analytic Hierarchy Process (FAHP). FAHP is preferred since the use of fuzzy logic presents valuable advantages, with respect to more traditional AHP methods, as described and presented within the methodology section.

The FAHP method has been widely applied in researches related to tourism and also, in different disciplines that explore the social sciences. FAHP application in the tourism field can be summarized as follows: Tsaur, Tzeng and Wang (1997) used it to determine the assigned weightings for different tourist risk evaluation criteria. Tsaur and Wang (2007) equally applied FAHP whilst determining the assigned weightings for sustainable tourism development indicators for the Green Island in Taiwan. Chou, Hsu and Chen (2008) also used the fuzzy set theory method, linguistic values, hierarchical structure analysis and FAHP in identifying the international tourists preferred hotel location and its subsequent selection, in Taiwan. Lin, Lee and Chen (2009) applied FAHP in evaluating the service performance, for a foreign travel intermediary, by making use of the shared perspectives for a host travel agency and their vision. Fu, Chu, Chao, Lee and Liao (2011) have made use of the VIKOR technique that integrates FAHP, whilst reviewing a sample consisting of 26 five star international hotels, located in three large metropolises in Taiwan, to identify and benchmark enterprise and to also analyse, strategies for performing an assessment. Lastly, Ar, Baki and Özdemir (2014) equally integrated FAHP with fuzzy VIKOR techniques, for the selection of a suitable site intended for an eco-tourism center in Rize, Turkey. In addition, studies examining and assessing the tourism field based on the FAHP methodology are shown in Table 1. It is important to note that different approaches have been developed, over time and has made use of as well as applied the FAHP method. These four most frequently used methods are applied within this research. Consequently, it will be possible to test if the results from these approaches differ.

\section{Methodology \\ Data Collection}

In order to effectively compare the fuzzy ranking methods, used in evaluating tourism destination attributes, a survey was designed and conducted. The survey was conducted from September 3, 2015 up until December 8, 2015 and was used in determining as well as for the assignment of weightings, for attributes of Eskişehir. 
Table 1. FAHP based studies in tourism field

\begin{tabular}{|c|c|c|c|}
\hline Author & Approach & Data & Results \\
\hline $\begin{array}{l}\text { Wang, Jung, } \\
\text { Yeo and Chou } \\
(2014)\end{array}$ & $\begin{array}{l}\text { Factor analysis } \\
\text { and FAHP }\end{array}$ & $\begin{array}{l}121 \text { participants } \\
\text { consisting cruise } \\
\text { companies, agents, } \\
\text { brokers, port authorities } \\
\text { and researchers }\end{array}$ & $\begin{array}{l}\text { Tourism attractions were found to } \\
\text { be the most important evaluation } \\
\text { category, for cruise line operators, in } \\
\text { selecting a port of call or location }\end{array}$ \\
\hline $\begin{array}{l}\text { Mardani, } \\
\text { Jusoh, Bagheri } \\
\text { and Kazemilari } \\
(2014)\end{array}$ & $\begin{array}{l}\text { Fuzzy Delphi, } \\
\text { FAHP and Fuzzy } \\
\text { TOPSIS }\end{array}$ & $\begin{array}{l}14 \text { quality management } \\
\text { experts }\end{array}$ & $\begin{array}{l}\text { In terms of ensuring quality } \\
\text { management, critical success } \\
\text { factors - human and leadership - } \\
\text { were found as the most important } \\
\text { criterion and sub-criterion from the } \\
\text { evaluation }\end{array}$ \\
\hline $\begin{array}{l}\text { Chen, Yu, Tsui } \\
\text { and Lee (2014) }\end{array}$ & $\begin{array}{l}\text { Fuzzy Delphi and } \\
\text { FAHP }\end{array}$ & $\begin{array}{l}31 \text { experts consisting } \\
\text { professors, international } \\
\text { hotel managers and } \\
\text { international hotel VIP } \\
\text { guests }\end{array}$ & $\begin{array}{l}\text { Hospitality was identified as the } \\
\text { most essential criterion, for } \\
\text { successful international hotel } \\
\text { atmosphere design }\end{array}$ \\
\hline $\begin{array}{l}\text { Wang, Li, Zhen } \\
\text { and Zhang } \\
(2016)\end{array}$ & $\begin{array}{l}\text { Fuzzy } \\
\text { comprehensive } \\
\text { evaluation } \\
\text { method-AHP and } \\
\text { Importance- } \\
\text { performance } \\
\text { analysis }\end{array}$ & $\begin{array}{l}409 \text { participants } \\
\text { consisting tourists }\end{array}$ & $\begin{array}{l}\text { Smart information system, } \\
\text { intelligent tourism management, } \\
\text { smart sightseeing, e-commerce } \\
\text { system, smart safety, intelligent } \\
\text { traffic, smart forecasting and virtual } \\
\text { tourist attractions were obtained as } \\
\text { tourists' key evaluation factors for } \\
\text { smart tourist attraction }\end{array}$ \\
\hline $\begin{array}{l}\text { Chen and Bau } \\
(2016)\end{array}$ & $\begin{array}{l}\text { Factor analysis } \\
\text { and FAHP }\end{array}$ & $\begin{array}{l}50 \text { participants } \\
\text { consisting governmental } \\
\text { agencies, NGOs, } \\
\text { associations, operators, } \\
\text { local communities, } \\
\text { scholars and } \\
\text { beachgoers }\end{array}$ & $\begin{array}{l}\text { Cleanliness of the beach } \\
\text { environment was identified as the } \\
\text { most important beach evaluation } \\
\text { factor. In addition, water quality } \\
\text { standards was also presented as a } \\
\text { key attribute }\end{array}$ \\
\hline $\begin{array}{l}\text { Mardani, } \\
\text { Zavadskas, } \\
\text { Streimikiene, } \\
\text { Jusoh, Nor and } \\
\text { Khoshnoudi } \\
\text { (2016) }\end{array}$ & $\begin{array}{l}\text { Fuzzy Delphi, } \\
\text { FAHP and Fuzzy } \\
\text { TOPSIS }\end{array}$ & $\begin{array}{l}35 \text { experts consisting } \\
\text { industry and academic } \\
\text { professionals }\end{array}$ & $\begin{array}{l}\text { Equipment efficiency and efficient } \\
\text { solutions for active space cooling } \\
\text { were found as the key criterion and } \\
\text { sub-criterion. PEIH (Parsian } \\
\text { Esteghlal International Hotel) was } \\
\text { placed on the top having the largest } \\
\text { saving energy performance index } \\
\text { value }\end{array}$ \\
\hline
\end{tabular}

Outputs of descriptive analysis are shown in Table 2.

This survey was designed to be within Saaty's 9 point scale, for traditional AHP and was then transformed into fuzzy ratio scales composed of triangular fuzzy numbers, in a hierarchical structure as shown in Table 3. Four key evaluation criteria as well as nineteen sub- criteria, were included into the survey and are presented in Figure 1. The depth covered within the literature reviewed, by the researcher, was initiated in a bid to support the successful design of a scale and also, to effectively define the evaluation criteria and sub-criteria (Gearing, Swart and Var, 1974; Swarbrooke, 1995; Godfrey \& Clark, 2003; Ritchie, Goeffrey \& 
Table 2. Demographic variables of the study

\begin{tabular}{llll}
\hline Demographic Variables & Frequency & Percent (\%) \\
\hline Gender & Female & 12 & 44.44 \\
Age & Male & 15 & 55.56 \\
& $18-30$ & 1 & 3.70 \\
& $31-40$ & 14 & 51.85 \\
Experience in & $41-50$ & 7 & 25.92 \\
the tourism & $51-60$ & 5 & 18.51 \\
industry & $1-3$ & 3 & 11.11 \\
& $4-6$ & 4 & 14.81 \\
Education & -9 & 2 & 7.40 \\
& $10-12$ & 3 & 11.11 \\
Institution & $13-15$ & 15 & 15.56 \\
& Bachelor's degree & 18 & 66.67 \\
& Post-graduate & 3 & 11.11 \\
& Doctorate & 6 & 22.22 \\
& University (academicians) & 6 & 22.22 \\
& Public sector & 8 & 29.62 \\
& Private Sector (travel & 13 & 48.14 \\
\hline
\end{tabular}

Table 3. Fuzzy evaluation scores

\begin{tabular}{lll}
\hline $\begin{array}{l}\text { Saaty's relative } \\
\text { Importance }\end{array}$ & Linguistic Terms & Fuzzy Score \\
\hline$C_{\mathrm{ij}}=1$ & Equally important & $(1,1,2)$ \\
$\mathrm{C}_{\mathrm{ij}}=2$ & Intermittent value & $(1,2,3)$ \\
$\mathrm{C}_{\mathrm{ij}}=3$ & Weakly important & $(2,3,4)$ \\
$\mathrm{C}_{\mathrm{ij}}=4$ & Intermittent value & $(3,4,5)$ \\
$\mathrm{C}_{\mathrm{ij}}=5$ & Fairly important & $(4,5,6)$ \\
$\mathrm{C}_{\mathrm{ij}}=6$ & Intermittent value & $(5,6,7)$ \\
$\mathrm{C}_{\mathrm{ij}}=7$ & Strongly important & $(6,7,8)$ \\
$\mathrm{C}_{\mathrm{ij}}=8$ & Intermittent value & $(7,8,9)$ \\
$\mathrm{C}_{\mathrm{ij}}=9$ & Absolutely important & $(8,9,9)$ \\
\hline
\end{tabular}

Crouch, 2003; Eskişehir Tourism Master Plan, 2011; Üsküdar, Çakır \& Temizkan, 2014). After the required guidance procedure was completed, the data collection process was started. At the conclusion of the survey, 27 questionnaires were completed for the survey and its output information was collected and analyzed, using Excel 2013 Software.

\section{Fuzzy Sets Theory and Fuzzy Numbers}

Zadeh (1965) first proposed a mathematical theory, namely fuzzy sets, in order to overcome the vagueness and imprecise conditions related to the humans' cognitive processes (Jie, Meng \& Cheong, 2006, p.1). Fuzzy term refers to ambiguity and vagueness of a situation (Bellman 


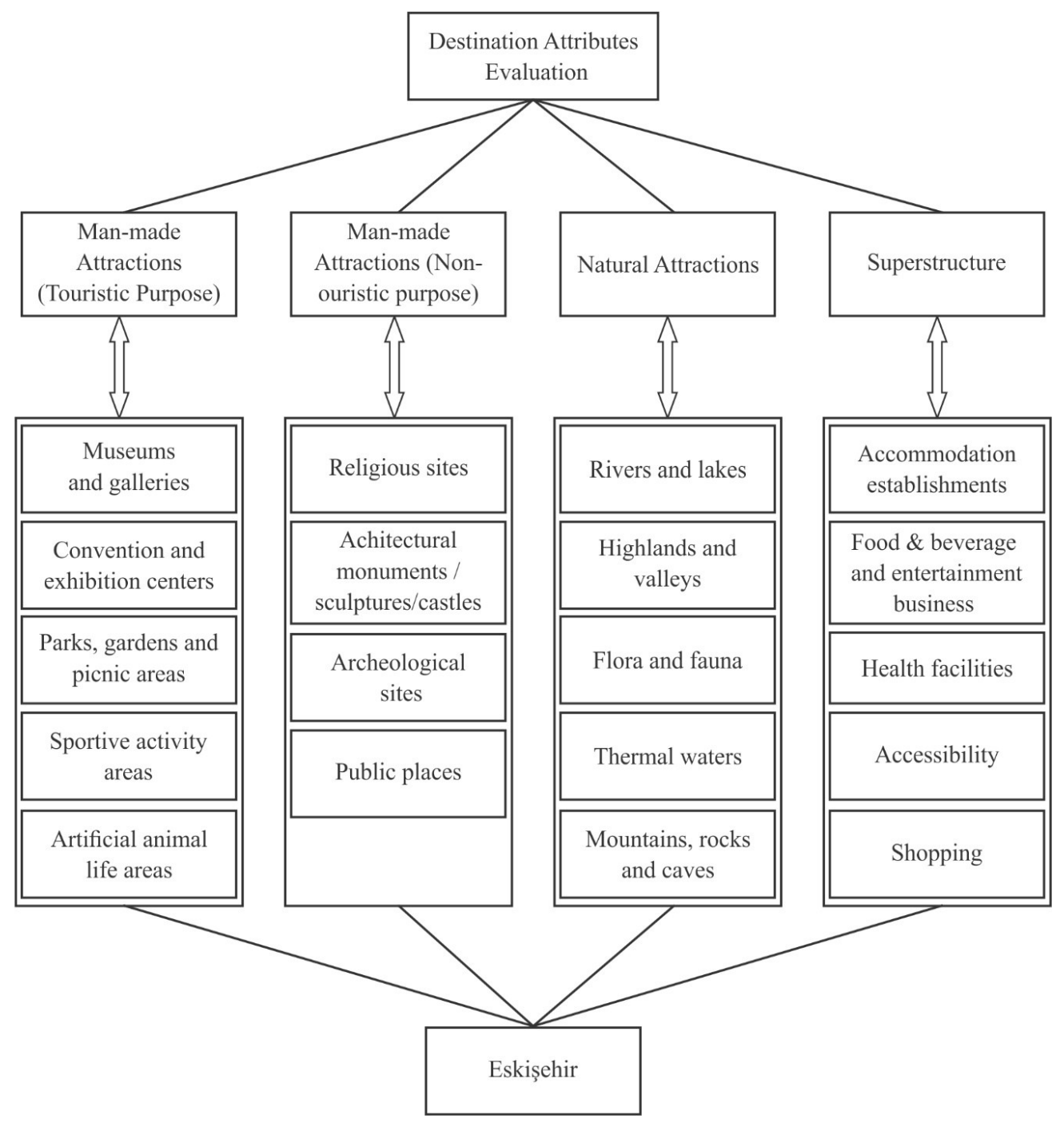

Figure 1. Criteria and sub-criteria for destination attractions

\& Zadeh, 1970; Zebda, 1989). Apart from classical set theory, based on binary logic, fuzzy sets attempt to describe actual objects similar to human language (Huang \& Ho, 2013, p. 983). A fuzzy set, which is an extension of the crisp one, allows partial belonging of element by membership function. The membership values of objects in a fuzzy set, range from 0 (nonmembership) to 1 (complete membership). The values between these defined boundaries are called intermediate membership degrees and show, the degree to which an element belongs to a set (Ertuğrul \& Karakaşoğlu, 2009, p.704). Fuzzy set theory is composed of classes with unsharp boundaries (Zadeh, 1994). According to Huang and Ho (2013) a fuzzy set $(\widetilde{B})$ can be defined as follows:

$\tilde{B}=\left\{\left(x, \mu_{\tilde{B}}(x)\right) \mid x \in G\right\}$

Where $\tilde{B}$ is fuzzy set and $G$ is the universe of discourse. In addition the membership function $\mu_{\tilde{B}}(x)$ ranges from between 0 and 1 .

Fuzzy logic provides a wider frame than classical sets and can handle real world applications more efficiently, when compared to traditional mathematical tools (Ertuğrul \& Tuş, 2007). It models uncertainty as well as complex situations, where there exists imprecise and incomplete information. Fuzzy logic takes into 
account human subjectivity and the imprecision of human behavior and then, tries to find a good approximate solution (Bojadziev \& Bojadziev, 1998).

Triangular and trapezoidal fuzzy numbers are the most used in practice (Baykal \& Beyan, 2004). Triangular fuzzy numbers are used in this study due to computational ease and its' representation usefulness. The membership of a triangular fuzzy number is defined by three real numbers expressed as $(\mathrm{l}, \mathrm{m}, \mathrm{u})$ indicating the smallest possible value, the most promising value and the largest possible value, respectively (Deng, 1999). The membership function, for triangular fuzzy numbers, is showed in the following equation (Jie, Meng \& Cheong, 2006):

$\mu_{\widetilde{M}}(x)=\left\{\begin{array}{c}\frac{(x-l)}{(m-l)}, l \leq x \leq m, \\ \frac{(u-x)}{(u-m)}, m \leq x \leq u, \\ 0, \text { otherwise }\end{array}\right.$

A triangular fuzzy number $(\widetilde{M})$ is shown in Figure 2 (Deng, 1999).

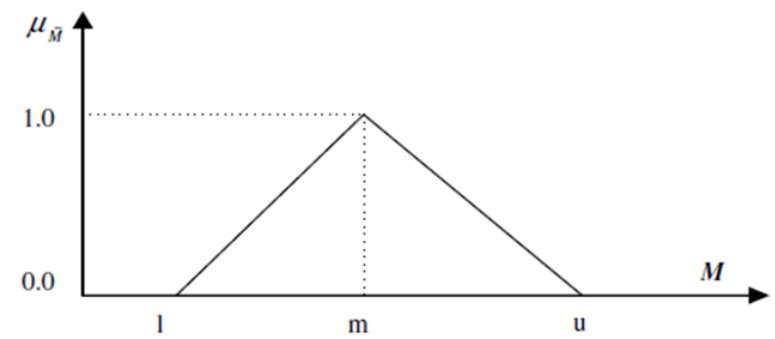

Figure 2. Triangular fuzzy number $(\tilde{M})$

Ranking fuzzy numbers in an imprecise and vague environment is one of the essential problems during fuzzy optimization and fuzzy decision making. Fuzzy values are ranked according to different specifications for fuzzy sets, namely center of attraction, area under the membership degree function and some intersection points. There are different fuzzy ranking methods for presenting various results of the same data, in the literature. Each method has its specific advantage as well as disadvantages, so it becomes fairly difficult to make a decision which method is best (Chen, Hwang \& Hwang, 1992). Various fuzzy ranking methods can be used according to the complexity, sensitivity, the ease of interpreting of existing problems, computational ease and type of fuzzy numbers (Kaptanoğlu \& Özok, 2006, p.198). Several fuzzy ranking methods have been examined within the literature for our study and these can be summarized and also, grouped in accordance with the adopted approach for: 'indexing of optimism' (Liou \& Wang, 1982; Kim \& Park, 1990; Abdel-Kader \& Dugdale, 2001; Yu \& Dat, 2014), the 'distance method' (Cheng, 1998; Yao \& Wu, 2000; Asady \& Zendehnam, 2007), 'possibility theory' (Dubois \& Prade, 1983; Matarazzo \& Munda, 2001; Qupeng \& Zuxing, 2017), 'unit interval' (Yager, 1981), 'maximizing and minimizing sets' (Chen, 1985; Raj \& Kumar, 1999), 'extent analysis' (Chang, 1996), 'column geometric mean' (Buckley, 1985), 'maximizing and minimizing barriers' (Choobineh \& Li, 1993), 'magnitude based ranking' (Abbasbandy \& Hajjari, 2009; Ezzati, Allahviranloo, Khezerloo \& Khezerloo, 2012), 'area between centroid and original points' (Chu \& Tsao, 2002; Wang \& Lee, 2008), 'preference ratio' (Modarres \& Nezhad, 2001), 'relative preference relation' (Wang, 2015), 'centroid based ranking' (Das \& Guha, 2016), 'area based ranking' (Deng, Zhenfu \& Qi, 2006; Kahraman \& Tolga, 2009) and ' $\alpha$-cut based ranking' (Shureshjani \& Darehmiraki, 2013).

\section{Fuzzy Analytic Hierarchy Process (FAHP)}

Analytic Hierarchy Process (AHP), as proposed by Saaty (1980), handles both qualitative and quantitative data in a bid to express a decision makers' opinion using a hierarchical structure (Ertuğrul \& Karakaşoğlu, 2009, p.705). But this technique is unable to consider decision makers' opinions in an imprecise and uncertain environment (Deng, 1999; Kahraman, Cebeci \& Ulukan, 2003). For this purpose, the Fuzzy Analytic Hierarchy Process (FAHP) composed of traditional AHP and fuzzy set theory is further proposed, in order to overcome fuzzy problems and explain subjective judgments in hierarchical way by using an interval judgment matrix (Kahraman et al., 2003; Wang, Fan \& Wang, 2010, p. 8518).

Fuzzy pairwise matrices including triangular fuzzy numbers are given as follows (Wang, Luo \& Hua, 2008: 736): 


$$
\tilde{B}=\left(\tilde{b}_{i j}\right)_{n x k}=\left[\begin{array}{cccc}
(1,1,1) & \left(l_{12}, m_{12}, u_{12}\right) & \cdots & \left(l_{1 k}, m_{1 k}, u_{1 k}\right) \\
\left(l_{21}, m_{21}, u_{21}\right) & (1,1,1) & \cdots & \left(l_{2 k}, m_{2 k}, u_{2 k}\right) \\
\vdots & \vdots & \vdots & \vdots \\
\left(l_{n 1}, m_{n 1}, u_{n 1}\right) & \left(l_{n 2}, m_{n 2}, u_{n 2}\right) & \cdots & (1,1,1)
\end{array}\right]
$$

Where $\tilde{b}_{i j}=\left(l_{i j}, m_{i j}, u_{i j}\right), \tilde{b}_{i j}^{-1}=\left(\frac{1}{u_{j i}}, \frac{1}{m_{j i}}, \frac{1}{l_{j i}}\right)$ for $1,2, \ldots, n, j=1,2, \ldots, k$ elements and $i \neq j$.

By using fuzzy pairwise matrices, the relative importance of element i over element j, according to decision makers, is obtained.

\section{Buckley's Column Geometric Mean Method (1985)}

Buckley (1985) proposed a method that is based on column geometric mean for ranking triangular fuzzy numbers.

\section{Liou and Wang Method (1992)}

Any triangular fuzzy number is ranked by considering total integral value, neglecting type and normality of membership function, according to Liou and Wang (1992). For a triangular fuzzy number such as $\tilde{B}=(l, m, u)$ the total integral value is calculated as shown in Eq. (4):

$$
\begin{aligned}
& I_{V}^{\alpha}(B)=\frac{1}{2} \alpha(m+u)+\frac{1}{2}(1-\alpha)(l+m)= \\
& \frac{1}{2}[\alpha u+m+(1-\alpha) l]
\end{aligned}
$$

According to the index of optimism defined by $\alpha \in[0,1]$, a decision maker has an optimistic $(\alpha=1)$, consensus $(\alpha=0.5)$ or pessimistic $(\alpha=0)$ viewpoint. The values for these index depend on the decision makers. Any two triangular fuzzy numbers such as $\tilde{B}_{1}$ and $\widetilde{B}_{2}$ can be compared as shown in Eq. (5):

$$
\begin{aligned}
& I_{V}^{\alpha}\left(\tilde{B}_{1}\right)<I_{V}^{\alpha}\left(\widetilde{B}_{2}\right) \rightarrow \widetilde{B}_{1}<\tilde{B}_{2} \\
& I_{V}^{\alpha}\left(\tilde{B}_{1}\right)=I_{V}^{\alpha}\left(\widetilde{B}_{2}\right) \rightarrow \widetilde{B}_{1}=\widetilde{B}_{2} \\
& I_{V}^{\alpha}\left(\tilde{B}_{1}\right)>I_{V}^{\alpha}\left(\widetilde{B}_{2}\right) \rightarrow \widetilde{B}_{1}>\widetilde{B}_{2}
\end{aligned}
$$

\section{Chang's Extent Analysis Method on FAHP (1996)}

Chang (1996) proposed an approach for dealing with FAHP by using triangular fuzzy numbers for pairwise comparison and also, considering the extent analysis for the synthetic extent values of comparisons. Extent analysis is carried out to obtain crisp weight vectors from the fuzzy pairwise matrices. Let $X=\left\{x_{1}, x_{2}, \ldots, x_{n}\right\}$ be an object set and $G=\left\{g_{1}, g_{2}, \ldots, g_{n}\right\}$ be a goal set. According to Chang's (1996) extent analysis each objective is taken and an extent analysis for each goal is performed, respectively. So, $\mathrm{m}$ extent analysis values $(j=1,2, \ldots, m)$ for each object $(i=1,2, \ldots, n)$ can be obtained with the following signs:

$M_{g i}^{1}, M_{g i}^{2}, \cdots, M_{g i}^{m} i=1,2, \cdots, n$

Where all the $M_{g i}^{j}$ are triangular fuzzy numbers and are the values for an extent analysis of ith object for $m$ goals.

\section{Abdel-Kader and Dugdale Method (2001)}

Any triangular fuzzy number is ranked by using an index of optimism $(\alpha)$ from within the closed interval of $[0,1]$ and considering the three parts reflect full membership located in the middle and partial memberships located in the left and right hand-sides, according to the Abdel- Kader and Dugdale (2001).

For $N$ fuzzy numbers $(r=1,2, \ldots, N)$

$\tilde{B}_{1}=\left(l_{1}, m_{1}, u_{1}\right), \tilde{B}_{2}=\left(l_{2}, m_{2}, u_{2}\right), \ldots, \tilde{B}_{r}=\left(l_{r}, m_{r}, u_{r}\right)$. Assume that $K=\left(l_{1}, m_{1}, u_{1}, l_{2}, m_{2}, u_{2}, \ldots, l_{r}, m_{r}, u_{r}\right)$ and $V\left(\tilde{B}_{r}\right)$ which is the value of $\tilde{B}_{r}$ can be calculated as follows:

$$
\begin{aligned}
V\left(\tilde{B}_{r}\right)= & m_{r}\left\{\alpha\left[\frac{u_{r}-x_{\min }}{x_{\max }-x_{\min }+u_{r}-m_{r}}\right]+(1-\alpha)[1-\right. \\
\left.\left.x_{\max -x_{\min }+m_{r}-l_{r}}\right]\right\} & \\
x_{\min }= & \inf K \\
x_{\max } & =\operatorname{supK}
\end{aligned}
$$

\section{Results}

In order to calculate the weights for the main criteria and sub-criteria, Buckley's (1985) column geometric mean method; Chang's (1996) extent analysis method; Liou and Wang (1992) method as well as the Abdel-Kader and Dugdale (2001) methods, have been adopted. Thus, weights acquired from these different methods were compared. 
Firstly, a transformed fuzzy ratio scale is used for constructing the pairwise comparison matrix by decision makers. Based on the Chang's extension method, weights of the main criteria namely natural resources and superstructure being zero so to overcome this disadvantage firstly Saaty's 9-point scale is carried out by decision maker's to construct pairwise comparison matrix. Then, by adopting Eq. (10) as proposed by Chen, Lin and Huang (2006) the decision makers' pairwise comparison values are transformed into triangular fuzzy numbers and a comprehensive pairwise comparison matrix is acquired. Let the fuzzy rating and importance weight for the rth decision maker be $\tilde{b}_{i j r}=\left(x_{i j r}, y_{i j r}, z_{i j r}\right) ; i=1,2, \ldots, m$ and $j=$ $1,2, \ldots, n$ respectively. So the aggregated fuzzy ratings $\left(\tilde{b}_{i j}\right)$ of alternatives, with respect to each criterion, can be calculated as below:

$$
\begin{aligned}
& \left(\tilde{b}_{i j}\right)=\left(x_{i j}, y_{i j}, z_{i j}\right) \text { where } \\
& x_{i j}=\min _{r}\left\{x_{i j r}\right\}, y_{i j}=\frac{1}{R} \sum_{r=1}^{R} y_{i j r}, z_{i j}=\max _{r}\left\{z_{i j r}\right\}
\end{aligned}
$$

Sample normal and fuzzy pairwise comparison matrices with respect to criteria are given in Table 4 and 5 respectively:

After applying the four fuzzy ranking methods, weights and ranks (given in parenthesis) for the criteria were acquired and presented in Table 6:

As seen from Table 6, among the four attributes examined, man-made (touristic purpose) was identified as the most important attribute according to the fuzzy ranking methods adopted by this study. On the other hand, superstructure criteria was found as the least important attribute

Table 4. Normal pairwise comparison matrix value with respect to criteria

\begin{tabular}{lcccc}
\hline Criteria & $\begin{array}{l}\text { Man-made } \\
\text { (touristic purpose) }\end{array}$ & $\begin{array}{l}\text { Man-made (non- } \\
\text { touristic purpose) }\end{array}$ & $\begin{array}{l}\text { Natural } \\
\text { attributes }\end{array}$ & Superstructure \\
\hline $\begin{array}{l}\text { Man-made } \\
\text { (touristic purpose) }\end{array}$ & 1 & $1 / 7$ & 7 & $1 / 5$ \\
Man-made (non- & 7 & & & \\
touristic purpose) & $1 / 7$ & 1 & $1 / 3$ & 7 \\
$\begin{array}{l}\text { Natural attributes } \\
\text { Superstructure }\end{array}$ & 5 & 3 & 1 & 3 \\
\hline
\end{tabular}

Table 5. Fuzzy pairwise comparison matrix value with respect to criteria

\begin{tabular}{lllll}
\hline Criteria & $\begin{array}{l}\text { Man-made } \\
\text { (touristic purpose) }\end{array}$ & $\begin{array}{l}\text { Man-made (non- } \\
\text { touristic purpose) }\end{array}$ & $\begin{array}{l}\text { Natural } \\
\text { attributes }\end{array}$ & Superstructure \\
\hline $\begin{array}{l}\text { Man-made } \\
\text { (touristic purpose) }\end{array}$ & $(1,1,1)$ & $(1 / 8,1 / 7,1 / 6)$ & $(6,7,8)$ & $(1 / 6,1 / 5,1 / 4)$ \\
$\begin{array}{l}\text { Man-made (non- } \\
\text { touristic purpose) }\end{array}$ & $(6,7,8)$ & $(1,1,1)$ & & \\
Natural attributes & $(1 / 8,1 / 7,1 / 6)$ & $(2,3,4)$ & $(1 / 4,1 / 3,1 / 2)$ & $(6,7,8)$ \\
Superstructure & $(4,5,6)$ & $(1 / 8,1 / 7,1 / 6)$ & $(1 / 1,1)$ & $(2,3,4)$ \\
\hline
\end{tabular}

Table 6. Weights and ranks of criteria according to different fuzzy ranking methods

\begin{tabular}{lllll}
\hline Criteria & Chang's Method & $\begin{array}{l}\text { Buckley's } \\
\text { Method }\end{array}$ & $\begin{array}{l}\text { Liou and Wang } \\
\text { Method }\end{array}$ & $\begin{array}{l}\text { Abdel-Kader } \\
\text { and Dugdale }\end{array}$ \\
\hline $\begin{array}{l}\text { Man-made } \\
\text { (touristic purpose) }\end{array}$ & $0.38562(1)$ & $0.40436(1)$ & $0.40715(1)$ & $0.57141(1)$ \\
$\begin{array}{l}\text { Man-made (non- } \\
\text { touristic purpose) }\end{array}$ & $0.37850(2)$ & $0.33359(2)$ & $0.30987(2)$ & $0.32282(2)$ \\
$\begin{array}{l}\text { Natural attributes } \\
\text { Superstructure }\end{array}$ & $0.11877(3)$ & $0.15076(3)$ & $0.18080(3)$ & $0.09163(3)$ \\
\hline
\end{tabular}


to be evaluated. However, manmade (nontouristic purpose) and natural attributes were ranked as the second and third most important criteria based on the four different fuzzy ranking methods respectively. Accordingly, global weights and ranks of sub-criteria are obtained and presented in Table 7:

According to the derived global weights for subcriteria being evaluated, shopping and health facilities were found to be the two lowest ranked, from among the 19 attributes examined, based on the adopted fuzzy ranking methods. In addition, the rankings for other sub-criteria examined differentiate for used fuzzy ranking methods. For instance, while archaeological sites were found as the most important attribute according to Liou and Wang (1982), Chang's
(1996) and the Buckley's (1985) methods, activity areas were identified as the most important for Abdel-Kader and Dugdale (2001) method.

These four methods adopted reveal the same main criteria ranking and also, similar main criteria weights. Based on output from a nonparametric Friedman test, there is no significant difference (>.05) between all of the four methods explored, in terms of the derived main criteria weights.

Conversely, the four methods produce different results in terms of derived sub-criteria weights and ranking. Archaeological sites were identified as the best sub-criteria for Chang's (1996), Buckley's (1985) and the Liou \& Wang (1982)

Table 7. Global weights and ranks (given in parenthesis) of sub-criteria according to different fuzzy ranking methods

\begin{tabular}{|c|c|c|c|c|}
\hline Sub-criteria & $\begin{array}{l}\text { Chang's } \\
\text { Method }\end{array}$ & $\begin{array}{l}\text { Buckley's } \\
\text { Method }\end{array}$ & $\begin{array}{l}\text { Liou-Wang } \\
\text { Method }\end{array}$ & $\begin{array}{l}\text { Abdel-Kader and } \\
\text { Dugdale Method }\end{array}$ \\
\hline Museum and galleries & $0.07922(6)$ & $0.10866(3)$ & $0.11901(3)$ & $0.22220(2)$ \\
\hline $\begin{array}{l}\text { Convention and } \\
\text { exhibition centers }\end{array}$ & $0.07471(9)$ & $0.04328(9)$ & $0.04354(9)$ & $0.01293(10)$ \\
\hline $\begin{array}{l}\text { Parks, gardens and } \\
\text { picnic areas }\end{array}$ & $0.07677(7)$ & $0.06587(5)$ & $0.06334(5)$ & $0.04649(5)$ \\
\hline Activity areas & $0.07969(5)$ & $0.13841(2)$ & $0.13345(2)$ & $0.27072(1)$ \\
\hline $\begin{array}{l}\text { Artificial animal life } \\
\text { areas }\end{array}$ & $0.07521(8)$ & $0.04812(7)$ & $0.04780(7)$ & $0.01904(8)$ \\
\hline Religious sites & $0.09146(3)$ & $0.02144(15)$ & $0.01778(17)$ & $0.00086(17)$ \\
\hline $\begin{array}{l}\text { Architectural } \\
\text { monuments/ } \\
\text { sculptures/castles }\end{array}$ & $0.09704(2)$ & $0.09186(4)$ & $0.10523(4)$ & $0.10140(4)$ \\
\hline Archaeological sites & $0.10042(1)$ & $0.18993(1)$ & $0.15295(1)$ & $0.21255(3)$ \\
\hline Public spaces & $0.08957(4)$ & $0.03033(12)$ & $0.03389(12)$ & $0.00799(11)$ \\
\hline Rivers and lakes & $0.02378(13)$ & $0.03265(11)$ & $0.04503(8)$ & $0.02690(7)$ \\
\hline Highlands and valley & $0.02309(17)$ & $0.01838(17)$ & $0.02400(14)$ & $0.00465(13)$ \\
\hline Flora and fauna & $0.02344(16)$ & $0.03386(10)$ & $0.03578(11)$ & $0.01537(9)$ \\
\hline Thermal waters & $0.02449(10)$ & $0.01975(16)$ & $0.02135(16)$ & $0.00299(15)$ \\
\hline $\begin{array}{l}\text { Mountains, rocks and } \\
\text { caves }\end{array}$ & $0.02395(12)$ & $0.04610(8)$ & $0.05461(6)$ & $0.04170(6)$ \\
\hline $\begin{array}{l}\text { Accommodation } \\
\text { establishments }\end{array}$ & $0.02367(15)$ & $0.02408(13)$ & $0.02289(15)$ & $0.00270(16)$ \\
\hline $\begin{array}{l}\text { Food \& beverage and } \\
\text { entertainment business }\end{array}$ & $0.02378(14)$ & $0.02250(14)$ & $0.02499(13)$ & $0.00324(14)$ \\
\hline Health facilities & $0.02308(18)$ & $0.01021(18)$ & $0.01214(18)$ & $0.00068(18)$ \\
\hline Accessibility & $0.02446(11)$ & $0.04916(6)$ & 0.03771 (10) & $0.00746(12)$ \\
\hline Shopping & 0.02206 (19) & 0.00530 (19) & 0.00442 (19) & $0.00002(19)$ \\
\hline
\end{tabular}


methods. Apart from these methods, activity areas were equally identified as the best subcriteria by the Abdel-Kader and Dugdale (2001) method. However shopping and health facilities were found as the worst two sub-criteria for all methods. According to outputs for the nonparametric Friedman test, there is a significant difference $(<.05)$ between the four methods examined in terms of sub-criteria weights. Test outputs are given in Table 8:

\section{Conclusion and Discussion \\ Contribution}

According to results obtained from using the four FAHP approaches identified, the ranking for the main criteria is found to be a similar trend with all the methods examined. Furthermore, the difference from methods used is not statistically significant and this is confirmed by the result of a non-parametric Friedman test, as seen in Table 8. When sub-criteria rankings are considered, the highest and lowest ranked variables can be identified as being similar, based on the four FAHP approaches adopted and is displayed in Table 7. For example, while archaeological sites, architectural monuments, museums and galleries were determined as the highest ranked sub-criteria; health facilities, shopping and religious sites were identified as the lowest ranked ones. Despite the fact that the four FAHP approaches adopted uncover similar ranking results, in terms of the most and least important ones, it is not considered valid for the remaining. It becomes obvious that there are fluctuations in the ranking of sub-criteria, such as public spaces, rivers and lakes, accessibility, mountains as well as rocks and caves, are identified from within different approaches examined. Sub-criteria have different weights in each approach examined and this can be seen from Table 7. This difference is statistically significant and it is supported by the results from the non-parametric Friedman test (see Table 8).

It is also understood from results of this research that manmade attributes (both touristic and nontouristic) were found as the most important criteria, according to the perceptions of tourism experts. Also, tourism experts perceive Eskişehir as a cultural destination which appeals to tourists especially with its archaeological and museum sites. However, the most important attribute affecting the tourists' destination choice decisions is natural according to the results of past researches (e.g. Correia et al., 2007; Çakıcı \& Harman, 2007; Mihalic, 2013). This research, however, does not particularly support such output result as outlined in the literature. This difference can be accepted as normal due to the content and sample used for this study. For instance, Correia et al. (2007) examined the tourists who travelled to exotic destinations and the sample of the Çakıcı and Harman (2007) research is made up of birdwatchers. Therefore, it is anticipated that the evaluation conducted will output natural attributes, as the highest ranked one. Man-made resources have been identified as the most important attribute, according to results from this research in comparison to past research studies, which idenified the most important attribute as natural ones. This distinction may arise from conducting this study on Eskişehir, which may possess its disadvantages, in terms of natural resources. However, it is famous for its historical and cultural wealth.

Table 8. Friedman test statistics for different methods in terms of criteria and sub-criteria

\begin{tabular}{|c|c|c|c|c|c|c|c|}
\hline & \multicolumn{3}{|l|}{$\begin{array}{l}\text { Mean Weight } \\
\text { (Criteria) }\end{array}$} & \multicolumn{4}{|c|}{$\begin{array}{l}\text { Mean Weight } \\
\text { (Sub-criteria) }\end{array}$} \\
\hline Chang's method & \multicolumn{3}{|l|}{2.50} & \multicolumn{4}{|c|}{2.74} \\
\hline Buckley's method & \multicolumn{3}{|l|}{2.50} & \multicolumn{4}{|c|}{2.63} \\
\hline $\begin{array}{l}\text { Liou and Wang } \\
\text { method }\end{array}$ & \multicolumn{3}{|l|}{2.25} & \multicolumn{4}{|c|}{2.95} \\
\hline $\begin{array}{l}\text { Abdel-Kader and } \\
\text { Dugdale method }\end{array}$ & \multicolumn{3}{|l|}{2.75} & \multicolumn{4}{|c|}{1.68} \\
\hline \multirow{2}{*}{$\begin{array}{l}\text { Friedman Test } \\
\text { Statistics }\end{array}$} & $\begin{array}{ll}\text { N } & \begin{array}{l}\text { Chi- } \\
\text { Square }\end{array}\end{array}$ & df & Sig & $\mathbf{N}$ & $\begin{array}{l}\text { Chi- } \\
\text { Square }\end{array}$ & df & Sig \\
\hline & $\begin{array}{ll}4 & 0.3\end{array}$ & 3 & 0.96 & 19 & 10.7 & 3 & 0.013 \\
\hline
\end{tabular}




\section{Managerial and Policy Implications}

In this research, where the attributes for Eskişehir have been examined, using the offered viewpoints of tourism experts and have been considered, the most important of criteria affecting the tourists' destination choice decision, were found to be man-made. In addition, archaeological sites and activity areas were identified as being essential sub-criteria. The shared perceptions of tourism experts should ideally be translated into practice, in relation to its existing man-made resource for Eskişehir, which must be protected and enhanced. In addition, the tourism inventory for Eskişehir needs to be further enriched, in terms of its available quality as well as quantity. In this way, at least the existing tourist market share will be retained because their post-visit attitudes, will be positively affected as they have a desirable experience whilst in Eskişehir. Furthermore, this destination is anticipated as likely to attract more visitors with its augmented destination inventory. Unfortunately, natural resources are not perceived as important, according to tourism experts engaged with. In fact, tourism has been identified as an industry that is highly dependent on its available resources. Consequently, a sustainable approach needs to be adopted by the supply side of tourism.

\section{Limitations}

The sample consists of just 27 completed questionnaires, due to the research's time and budget constraints. Also, the study found it fairly difficult to acquire a sufficient or larger sample size, for the survey required. In addition to these constraints, the data collection process took a long time because respondents were not familiar with the survey form format, which was based on an experts' view apart from the other usual parameters examined (likert scaling etc.). In order to gain a more reliable, valid and generalizable result, the sample size to be used should ideally be expanded on. These issues, however, are also considered to be some of the limitations faced by this study.

\section{Future Research}

The four different fuzzy ranking approaches adopted reveal the same results, in terms of the main criteria ranking. Furthermore, similarities of output results are achieved, with reference to the highest and lowest ranked sub criteria. This preliminary finding needs to be tested for its validity, in further researches related to tourism and in other fields as well. If future researches reveal similar results with this research, the ability in the future, to generalize the differing levels for these results, will offer an opportunity for advancement. This means that in a situation where the researcher decides to adopt fuzzy ranking methods in their research, they will likely obtain about the same type of results regardless of the approach adopted.

Lastly, the following additional suggestions were offered to researchers who are likely to conduct some research on this issue. These researches may be designed to take into consideration different destination attributes, especially tangible and intangible ones. Also, the sample size should be increased in order to reach more reliable and valid results. Same research construct can be applied to different types of destinations (resort, urban, rural etc.) and as a result it becomes possible to make comparisons between the results for these researches. Actually, these fuzzy ranking methods examined can be used when analyzing hierarchical structures within the tourism industry via collection of data from tourists, experts, local residents, investors, suppliers or any other tourism stakeholders, given the purpose of this research. Furthermore the different weighting and ranking methods can be integrated with and then applied to various other tourism topics.

\section{References}

Abbasbandy, S., T. Hajjari (2009). A new approach for ranking of trapezoidal fuzzy numbers. Computers \& Mathematics with Applications, 57(3), 413-419.

Abdel-Kader, M.G., D. Dugdale (2001). Evaluating Investments in Advanced Manufacturing Technology: A Fuzzy Set Theory Approach. British Accounting Review, 33, 455-489.

Ar, I.M., B. Baki, F. Özdemir (2014). Kuruluş Yeri Seçiminde Bulanık AHS-VIKOR Yaklaşımının Kullanımı: Otel Sektöründe Bir Uygulama. International Journal of Economic and Administrative Studies, 7(13), 93-114.

Asady, B., A. Zendehnam (2007). Ranking fuzzy numbers by distance minimization. Applied 
Mathematical Modelling, 31(11), 25892598.

Baykal, N., T. Beyan (2004). Bulanık Mantık Ilke ve Temelleri. Ankara, Bıçaklar Kitabevi.

Bellman, R., L.A. Zadeh (1970). Decisionmaking in a fuzzy environment. Management Science, 17(4), 141-164.

Bojadziev, G., M. Bojadziev (1998). Fuzzy sets fuzzy logic applications. Singapore: World Scientific Publishing.

Buckley, J.J. (1985). Ranking alternatives using fuzzy numbers. Fuzzy Sets and Systems, 29, 145-153.

Çakıcı, A. C., S. Harman (2007). Importance of Destination Attributes Affecting Destination Choice of Turkish Birdwatchers. Journal of Commerce \& Tourism Education Faculty, 1, 131-145.

Chacho, H. E., G.G. Fenich (2000). Determining the Importance of US Convention Destination Attributes. Journal of Vacation Marketing, 6(3), 211-220.

Chan, F.T.S., N. Kumar (2007). Global supplier development considering risk factors using fuzzy extended AHP-based approach. Omega International Journal of Management Science, 35, 417-431.

Chang, D. Y. (1996). Applications of the extent analysis method on fuzzy AHP. European Journal of Operational Research, 95, 649655.

Chang, Y.H., C.H. Cheng, T.C. Wang (2003). Performance evaluation of international airports in the region of East Asia. In Proceedinds of Eastern Asia Society for transportation studies, 4, 213-230.

Chen, C.L., Y.P. Bau (2016). Establishing a multi-criteria evaluation structure for tourist beaches in Taiwan: A foundation for sustainable beach tourism. Ocean \& Coastal Management, 121, 88-96.

Chen, C.T., C.T. Lin, S.F. Huang (2006). A Fuzzy Approach for Supplier Evaluation and Selection in Supply Chain Management. International Journal of Production Economics, 102(2), 289-301.

Chen, S.C., C. Hwang, F. Hwang (1992). Fuzzy Multiple Attribute Decision Making: Methods and Applications, SpringerVerlag: New York.

Chen, S.H. (1985). Ranking fuzzy numbers with maximizing set and minimizing set. Fuzzy Sets and Systems, 17, 113-129.
Chen, Y.C., T.H. Yu, P.L. Tsui, C.S. Lee (2014). A fuzzy AHP approach to construct international hotel spa atmosphere evaluation model. Quality \& Quantity, 48(2), 645-657.

Cheng, C.H. (1998). A New Approach for Ranking Fuzzy Numbers by Distance Method. Fuzzy Sets and Systems, 95, 307317.

Choobineh, F., H. Li (1993). An Index for Ordering Fuzzy Numbers. Fuzzy Sets and Systems, 54(3), 287-294.

Chou, T.Y., G.S. Liang (2001). Application of a Fuzzy Multi-criteria Decision Making Model for Shipping Company Performance Evaluation. Maritime Policy \& Management, 28(4), 375-392.

Chou, T.Y., C.L. Hsu, M.C. Chen (2008). A fuzzy multi-criteria decision model for international tourist hotels location selection. International Journal of Hospitality Management, 27(2), 293-301.

Chu, T.C., C.T. Tsao (2002). Ranking fuzzy numbers with an area between the centroid point and the original point. Computers \& Mathematics with Applications, 43 (1-2), 111-117.

Coltman, M. M. (1989). Introduction to Travel and Tourism: An International Approach. New York: Van Nostrand Reinhold.

Cook, R. A., L.J.Yale, J.J. Marqua (2010). Tourism: The Business of Travel $\left(4^{\text {th }}\right.$ Edition). New Jersey: Pearson.

Correia, A., P.O.D. Valle, C. Moço (2007). Modeling Motivations and Perceptions of Portuguese Tourists. Journal of Business Research, 60(1), 76-80.

Crompton, J. L. (1977). A Systems Model of the Tourist's Destination Selection Decision Process with Particular Reference to the Role of Image and Perceived Constraints. Unpublished Doctoral Dissertation, Texas A\&M University.

Crompton, J. L. (1979). Motivations for Pleasure Vacation. Annals of Tourism Research, 6(4), 408-424.

Dann, G. M. S. (1977). Anomie, EgoEnhancement and Tourism. Annals of Tourism Research, 4(4), 184-194.

Das, S., D. Guha (2016). A centroid-based ranking method of trapezoidal intuitionistic fuzzy numbers and its application to 
MCDM problems. Fuzzy Information and Engineering, 8(1), 47-74.

Demir, Ş. Ş. (2010). Çekici Faktörlerin Destinasyon Seçimine Etkisi: Dalyan Örneği. Ege Akademik Bakış, 10(3), 1041-1054.

Deng, H. (1999). Multicriteria analysis with fuzzy pairwise comparison. International Journal of Approximate Reasoning, 21, 215-231.

Deng, Y., Z. Zhenfu, L. Qi (2006). Ranking fuzzy numbers with an area method using radius of gyration. Computers \& Mathematics with Applications, 51(6-7), 1127-1136.

Dubois, D., H. Prade (1978). Operations on Fuzzy Number. International Journal of Systems Science, 9, 613-626.

Echtner, C. M., B.J.R. Ritchie (1993). The Measurement of Destination Image: An Emprical Assessment. Journal of Travel Research, 31(4), 3-13.

Enea, M., T. Piazza (2004). Project selection by constrained fuzzy AHP. Fuzzy Optimization and Decision Making, 3(1), 39-62.

Ertuğrul, İ., N. Karakaşoğlu (2009). Performance evaluation of Turkish cement firms with fuzzy analytic hierarchy process and TOPSIS methods, Expert Systems with Applications, 36, 702-715.

Ertuğrul, İ., A.Tuş (2007). Interactive fuzzy linear programming and an application sample at a textile firm. Fuzzy Optimization and Decision Making, 6, 29-49.

Evren, S., N.Kozak (2012). Eskişehir'in Çekicilik Faktörlerinin Günübirlik Ziyaretçilerin Bakış Açılarıyla Değerlendirilmesi, Anatolia: Turizm Araştırmaları Dergisi, 23(2), 220232.

Ezzati, R., T.Allahviranloo, S.Khezerloo, M. Khezerloo (2012). An Approach for Ranking of Fuzzy Numbers. Expert Systems with Applications, 39(1), 690-695.

Fu, H.P., K.K. Chu, P. Chao, H.H.Lee, Y.C.Liao (2011). Using fuzzy AHP and VIKOR for benchmarking analysis in the hotel industry. The Service Industries Journal, 31(14), 2373-2389.

Goeldner, C. R., J.R.Ritchie (2009). Tourism: Principles, Practices, Philosophies (11 th Edition). New York: John Wiley \& Sons, Inc.

Hsu, T. K., Y.F.Tsai, H.H. Wu (2009). The Preference Analysis for Tourist Choice of Destination: A Case Study of Taiwan. Tourism Management, 30(2), 288-297.
Huang, H.C., C.C. Ho (2013). Applying the fuzzy analytic hierarchy process to consumer decision-making regarding home stays, International Journal of Advancements in Computing Technology, 5(4), 981-990.

Hudson, S. (2008). Tourism and Hospitality Marketing: A Global Perspective. London, UK: Sage.

Jie, L, H., M.C.Meng, C.W. Cheong (2006) Web Based Fuzzy Multicriteria Decision Making Tool, International Journal of the Computer, the Internet and Management, 14(2), 1-14.

Kahraman, C., A.C. Tolga (2009). An alternative ranking approach and its usage in multicriteria decision-making. International Journal of Computational Intelligence, 2(3), 219-235.

Kahraman, C., U.Cebeci, D.Ruan (2004). Multiattribute comparison of catering service companies using fuzzy AHP: The case of Turkey. International Journal of Production Economics, 87, 171-184.

Kahraman, C., U.Cebeci, Z.Ulukan (2003). Multi-criteria supplier selection using fuzzy AHP. Logistics Information Management, 16(6), 382-394.

Kaptanoğlu, D., A.F.Özok (2006). Akademik Performans Değerlendirmesi İçin Bir Bulanık Model. ITÜ Dergisi/d mühendislik, 5(1), 193-204.

Kim, H. B. (1998). Perceived Attractiveness of Korean Destination. Annals of Tourism Research, 25(2), 340-361.

Kim, K., K.S.Park (1990). Ranking Fuzzy Numbers with Index of Optimism. Fuzzy Sets and Systems, 35,229-241.

Klenosky, D. B. (2002). The Pull of Tourism Destinastions: A Means-End Investigation. Journal of Travel Research, 40(4), 385395.

Lee, A.H.I., W.C.Chen, C.J. Chang (2008). A fuzzy AHP and BSC approach for evaluating performance of IT department in the manufacturing industry in Taiwan. Expert Systems with Applications, 34, 96-107.

Leiper, N. (1990). Tourist Attraction Systems. Annals of Tourism Research, 17(3), 367384.

Leiper, N. (1995) Tourism Management. TAFE Publications, Collingwood, Vic.

Lin, C.T., C.Lee, W.Y.Chen (2009). Using fuzzy analytic hierarchy process to evaluate 
service performance of a travel intermediary. The Service Industries Journal, 29(3), 281-296.

Liou, T.S., M.J.Wang (1992). Ranking fuzzy numbers with integral value. Fuzzy Sets and Systems, 50, 247-255.

Mardani, A., A. Jusoh, M.M. Bagheri, M. Kazemilari (2014). A combined hybrid fuzzy multiple criteria decision-making approach to evaluating of QM critical success factors in SME's hotels firms. Procedia - Social and Behavioral Sciences, 172, 786-793.

Mardani, A., E.K. Zavadskas, D. Streimikiene, A. Jusoh, K.M.D. Nor, M. Khoshnoudi (2016). Using fuzzy multiple criteria decision making approaches for evaluating energy saving technologies and solutions in five star hotels: A new hierarchical framework. Energy, 117(1), 131-148.

Matarazzo, B., G.Munda (2001). New Approach for the Comparison of L-R Fuzzy Numbers: A Theoretical and Operational Analysis. Fuzzy Sets and Systems, 118, 407-418.

McCabe, S. (2000). Tourism Motivation Process. Annals of Tourism Research, 27(4), 1049-1052.

Mihalic, T. (2013). Performance of Environmental Resources of a Tourist Destination: Concept and Application. Journal of Travel Research, 52(5) 614-630.

Mikulic, J., D.Kresic, K.Milicevic, M.Seric, B.Curkovic (2016). Destination Attractiveness Drivers among Urban Hostel Tourists: An Analysis of Frustrators and Delighters. International Journal of Tourism Research, 18, 74-81.

Modarres, M., S.S. Nezhad (2001). Ranking fuzzy numbers by preference ratio. Fuzzy Sets and Systems, 118(3), 429-436.

Pikkemaat, B. (2004). The Measurement of Destination Image: The Case of Austria. The Poznan University of Economics Review, 4(1), 87-102.

Pizam, A., Y.Mansfeld (1999). Consumer Behavior in Travel and Tourism. NY: The Haworth Hospitality Press.

Quupeng, G., X. Zuxing (2017). A new approach for ranking fuzzy numbers based on possibility theory. Journal of Computational and Applied Mathematics, 309, 674-682.

Raj, P.A., D.N.Kumar (1999). Ranking Alternatives with Fuzzy Weights Using
Maximizing Set and Minimizing Set. Fuzzy Sets and Systems, 105,365-375.

Ritchie, J.R.B., G.I.Crouch (2003). The Competitive Destination: A Sustainable Tourism Perspective, CABI Publishing, Wallingford, UK.

Saaty, T.L. (1980). The analytic hierarchy process. New York: McGraw-Hill.

Shureshjani, R.A., M. Darehmiraki (2013). A new parametric method for ranking fuzzy numbers. Indagationes Mathematicae, 24(3), 518-529.

Swarbrooke, J. (1995). The Development and Management of Visitor Attractions ( $1^{\text {th }}$ Edition). Oxford: Reed Elsevier.

Swarbrooke, J., S.Horner (1999). Consumer Behavior in Tourism (2 ${ }^{\text {nd }}$ Edition). Oxford: Butterworth-Heinemann.

Tisdell, C. A. (1991). Economics of Environmental Conservation: Economics for Environmental \& Ecological Management. Amsterdam: Elsevier.

Tsaur, S.H., C.H.Wang (2007). The evaluation of sustainable tourism development by Analytic Hierarchy Process and Fuzzy Set Theory: An empirical study on the Green Island in Taiwan. Asia Pasific Journal of Tourism Research, 12(2), 127-145.

Tsaur, S.H., G.H.Tzeng, K.C.Wang (1997). Evaluating tourist risks from fuzzy perspectives. Annals of Tourism Research, 24, 796-812.

Tüysüz, F., C.Kahraman (2006). Project risk evaluation using a fuzzy analytic hierarchy process: An application to information technology projects. International Journal of Intelligent Systems, 21, 559-584.

Uysal, M., C.Jurowski (1994). Testing the Push and Pull Factors. Annals of Tourism Research, 21(4), 844-846.

Van Laarhoven, P.J.M., W.Pedrcyz (1983). A Fuzzy Extension of Saaty's Priority Theory. Fuzzy Sets and Systems, 11, 229-241.

Van Raaij, W. F. (1986). Consumer Research on Tourism: Mental and Behavioural Constructs. Annual of Tourism Research, 13(1), 1-9.

Wang, J., K. Fan, W.Wang (2010). Integration of fuzzy AHP and FPP with TOPSIS methodology for aeroengine health assessment. Expert System with Applications, 37(12), 8516-8526. 
Wang, X., X.R. Li, F. Zhen, J. Zhang (2016). How smart is your tourist attraction? Measuring tourist preferences of smart tourism attractions via a FCEM-AHP and IPA approach. Tourism Management, 54, 309-320.

Wang, Y., K.A. Jung, G.T. Yeo, C.C. Chou (2014). Selecting a cruise port of call location using the fuzzy-AHP method: A case study in East Asia. Tourism Management, 42, 262-270.

Wang, Y.J. (2015). Ranking triangle and trapezoidal fuzzy numbers based on the relative preference relation. Applied Mathematical Modelling, 39(2), 586-599.

Wang, Y.J., H.S. Lee (2008). The revised method of ranking fuzzy numbers with an area between the centroid and original points. Computers \& Mathematics with Applications, 55(9), 2033-2042.

Wang, Y.M., Y.Luo, Z.Hua (2008). On the extent analysis method for fuzzy AHP and its' applications. European Journal of Operational Research, 186(2), 735-747.

Wong, I. A. (2011). Using Destination Attributes to Promote Event Travel: The Case of Macau. Journal of Convention \& Event Tourism. 12(4), 241-252.
Yager, R.R. (1981). A Procedure for Ordering Fuzzy Subsets of the Unit Interval. Information Sciences, 24, 143-161.

Yao, J.S., K.Wu (2000). Ranking Fuzzy Numbers Based on Decomposition Principle and Signed Distance. Fuzzy Sets and Systems, 116, 275-288.

Yu, V., L.Q. Dat (2014). An improved ranking method for fuzzy numbers with integral values. Applied Soft Computing, 14, 603608.

Zadeh, L.A. (1965). Fuzzy Sets. Information and Control, 8, 338-353.

Zebda, A. (1989). Fuzzy set theory and accounting. Journal of Accounting Literature, 8, 76-105.

Zhou, L. (2005). Destination Attributes That Attract International Tourists to Cape Town. Unpublished Master Thesis. University of the Western Cape. Cape Town: South Africa.

Zhou, Y., K.Maumbe, J.Deng, S.W. Selin (2015). Resource-based Destination Competitiveness Evaluation Using a Hybrid Analytic Hierarchy Process (AHP): The Case Study of West Virginia. Tourism Management Perspectives, 15, 72-80. 


\section{Appendices}

\section{Appendix 1.}

Steps for the Buckley's (1985) method are given as follows:

1- A hierarchical structure is established and a pairwise comparison matrice is constructed for comparing criteria or alternatives via fuzzy scale as shown below:

$\tilde{B}^{r}=\left[\begin{array}{cccc}\tilde{b}_{11}^{r} & \tilde{b}_{12}^{r} & \cdots & \tilde{b}_{1 n}^{r} \\ \tilde{b}_{21}^{r} & \tilde{b}_{22}^{r} & \cdots & \tilde{b}_{2 n}^{r} \\ \cdots & \cdots & \cdots & \cdots \\ \tilde{b}_{m 1}^{r} & \tilde{b}_{m 2}^{r} & \cdots & \tilde{b}_{m n}^{r}\end{array}\right]$

Where $\tilde{b}_{i j}^{r}$ denotes the performance rating of $i t h$ alternative $(i=1,2, \ldots, m)$ with regards to $j t h$ criterion $(j=1,2, \ldots, n)$ by $r t h$ decision maker $(r=1,2, \ldots, R)$ and the element of $\widetilde{B}^{r}$.

2- Preferences for all decision makers are averaged according to Eq. (12) and a new pairwise comparison matrix is obtained as Eq. (13):

$\tilde{b}_{i j}=\frac{\sum_{r=1}^{R} b_{i j}^{r}}{R}$

$\tilde{B}=\left[\begin{array}{cccc}\tilde{b}_{11} & \tilde{b}_{12} & \cdots & \tilde{b}_{1 n} \\ \tilde{b}_{21} & \tilde{b}_{22} & \cdots & \tilde{b}_{2 n} \\ \cdots & \cdots & \cdots & \cdots \\ \tilde{b}_{m 1} & \tilde{b}_{m 2} & \cdots & \tilde{b}_{m n}\end{array}\right]$

3- Geometric mean of each criterion is calculated according to Eq. (14):

$\tilde{h}_{i}=\left[\prod_{j=1}^{n} \tilde{b}_{i j}\right]^{1 / n} i=1,2, \ldots, m$

4- The fuzzy weights $\left(\widetilde{w}_{i}\right)$ for each criterion are obtained by finding the vector summation for each $\tilde{h}_{i}$, acquiring $(-1)$ power of summation vector and replacing it in an increasing order, and finally multiplying $\tilde{h}_{i}$ with a reverse vector according to Eq. (15):

$\widetilde{w}_{i}=\tilde{h}_{i} \otimes\left(\tilde{h}_{1} \oplus \tilde{h}_{2} \oplus \ldots \oplus \tilde{h}_{n}\right)^{-1}=\left(l_{i}, m_{i}, u_{i}\right)$
5- Fuzzy weights are transformed into crisp one by using the Center of Area defuzzification technique, shown in Eq. (16):

$K_{i}=\frac{l_{i}+m_{i}+u_{i}}{3}$

6- After obtaining crisp weights, normalization process is implemented such as Eq. (17):

$Z_{i}=\frac{K_{i}}{\sum_{i=1}^{m} K_{i}}$ 


\section{Appendix 2.}

Steps of the Chang's (1986) extent analysis can be given as follows:

1- The value of fuzzy synthetic extent with respect to the ith object is defined as:

$S_{i}=\sum_{j=1}^{m} M_{g i}^{j} \otimes\left[\sum_{i=1}^{n} \sum_{j=1}^{m} M_{g i}^{j}\right]^{-1}$

To obtain $\sum_{j=1}^{m} M_{g i}^{j}$ the fuzzy addition operation of $\mathrm{m}$ extent analysis values for a particular matrix is performed such as

$\sum_{j=1}^{m} M_{g i}^{j}=\left(\sum_{j=1}^{m} l_{j}, \sum_{j=1}^{m} m_{j}, \sum_{j=1}^{m} u_{j}\right)$

and to obtain $\left[\sum_{i=1}^{n} \sum_{j=1}^{m} M_{g i}^{j}\right]^{-1}$ the fuzzy addition operation of $M_{g i}^{j}(j=1,2, \ldots, m)$ values is performed such as

$\sum_{i=1}^{n} \sum_{j=1}^{m} M_{g i}^{j}=\left(\sum_{i=1}^{n} l_{i}, \sum_{i=1}^{n} m_{i}, \sum_{i=1}^{n} u_{i}\right)$

and then the inverse of the vector is computed as follows:

$\left[\sum_{i=1}^{n} \sum_{j=1}^{m} M_{g i}^{j}\right]^{-1}=\left(\frac{1}{\sum_{i=1}^{n} u_{i}}, \frac{1}{\sum_{i=1}^{n} m_{i}}, \frac{1}{\sum_{i=1}^{n} l_{i}}\right)$

2- The degree of possibility of $M_{2}=$ $\left(l_{2}, m_{2}, u_{2}\right), M_{1}=\left(l_{1}, m_{1}, u_{1}\right)$ is defined as:

$V\left(M_{2} \geq M_{1}\right)=\sup _{y \geq x}\left[\min \left(\mu_{M_{1}}(x), \mu_{M_{2}}(y)\right)\right]=$

$\operatorname{hgt}\left(M_{1} \cap M_{2}\right)=\mu_{M_{2}}(d)$ and can be expressed as follows:

$=\left\{\begin{array}{c}1, \text { if } m_{2} \geq m_{1} \\ 0, \text { if } l_{1} \geq u_{2} \\ \frac{l_{1}-u_{2}}{\left(m_{2}-u_{2}\right)-\left(m_{1}-l_{1}\right)}, \text { otherwise }\end{array}\right.$

Where $(x, y)$ is a pair, $\mathrm{d}$ is the ordinate of the highest intersection (hgt) point $\mathrm{D}$ between $\mu_{M_{1}}$ and $\mu_{M_{2}}$ and it is shown in Figure 3 (Chang, 1996). Values namely $M_{1}$ and $M_{2}$ are compared by using $V\left(M_{1} \geq M_{2}\right)$ and $\left(M_{2} \geq M_{1}\right)$.

3- The degree of possibility for a convex fuzzy number to be greater than $k$ convex fuzzy $M_{i}(i=$ $1,2, \cdots, k)$ numbers can be defined by

$V\left(M \geq M_{1}, M_{2}, \ldots, M_{k}\right)=V\left[\left(M \geq M_{1}\right)\right.$ and $(M \geq$ $\left.M_{2}\right)$ and $\ldots$ and $\left.\left(M \geq M_{k}\right)\right]=\operatorname{minV}\left(M \geq M_{i}\right), i=$ $1,2, \ldots, k$

Assume that $d\left(B_{i}\right)=\operatorname{minV}\left(S_{i} \geq S_{k}\right)$ for $k=$ $1,2, \ldots, n ; k \neq i$. Then the weight vector is given by

$W^{\prime}=\left(d^{\prime}\left(B_{1}\right), d^{\prime}\left(B_{2}\right), \ldots, d^{\prime}\left(B_{n}\right)\right)^{T}$

Where $B_{i}(i=1,2, \ldots, n)$ are $n$ elements

4- Via normalization, the normalized weight vectors are

$W=\left(d\left(B_{1}\right), d\left(B_{2}\right), \ldots, d\left(B_{n}\right)\right)^{T}$

Where $\mathrm{W}$ is a non-fuzzy number.

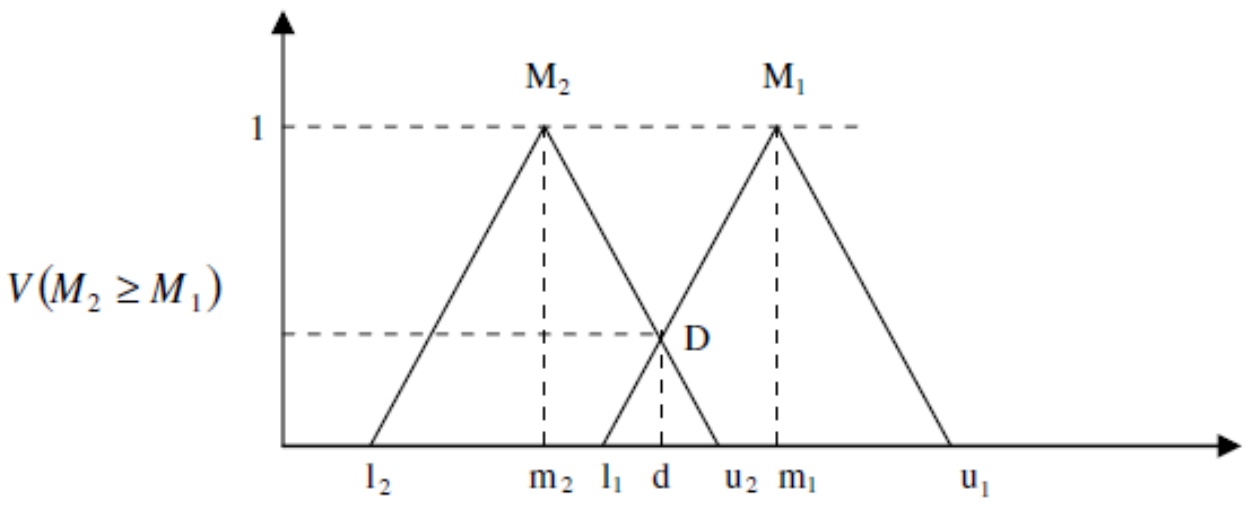

Figure 3. The definition of the degree of possibility of $\mathrm{V}\left(\mathrm{M}_{2} \geq \mathrm{M}_{1}\right)$ 